\title{
УЧАСТИЕ ТЕРРИТОРИАЛЬНОЙ ОБЩИНЫ В МЕСТНОМ ПУБЛИЧНОМ УПРАВЛЕНИИ: ПРОБЛЕМЫ И ПУТИ ИХ РЕШЕНИЯ
}

В статье рассматриваются проблемы низкого уровня участия членов сельских, поселковых, городских территориальных общин в решении вопросов местного значения в Украине и предложены пути их решения. Показаны процессы использования различных механизмов привлечения граждан к участию в местном публичном управлении в городах Украины, основанные на изучении мнения и выявлении приоритетов для населения касательно местной жизни путём их опроса и проведения анкетирования, объявления конкурсов и выдачи грантов, участия в Программе развития ООН.Анализируется понятие «социальное партнёрство» между территориальной общиной, муниципальными органами и органами государственной власти, представителями бизнес-структур, предприятиями разных форм собственности. Подчёркнуто, что отношения между субъектами местного самоуправления и государственными органами могут быть урегулированы путём передачи территориальным общинам большого количества прав и полномочий, которыми владеет государство. Определено приоритетное направление социального партнёрства представительских органов территориальной общины с жителями как деятельность органов местного самоуправления в сторону обеспечения интересов и потребностей обычного человека, который проживает на территории общины.

Определяется важность такого направления взаимодействия субъектов в сфере местного самоуправления, которое осуществляется на паритетной основе для вовлечения населения в процесс осуществления местного публичного управления в условиях реформирования местного самоуправления в Украине.

Показана значительность использования общественных совещательных советов (комитетов) как инструмента сотрудничества представителей территориальной общины и органов местного самоуправления на постоянной или временной основе. Выделяются вопросы, которыми должны заниматься постоянные и временные общественные советы, что может иметь значение для практической работы общественного совета и повлиять на результативность его деятельности.

Обосновывается необходимость проведения институциональных изменений в органах местного самоуправления и повышения уровня муниципального образования депутатов местных советов, должностных лиц местного самоуправления и граждан в рамках разработанной общегосударственной программы образования по вопросам местного самоуправлении. Для граждан предлагается использование местных

\footnotetext{
${ }^{1}$ Ирина Шумляева- кандидат наук по государственному управлению, доцент, доцент кафедры права и европейской интеграции Днепропетровского регионального института государственного управления Национальной академии государственного управления при Президенте Украины; communa @ yandex.ua

${ }^{2}$ Юлия Лисневская - кандидат политических наук, доцент кафедры права и европейской интеграции Днепропетровского регионального института государственного управления Национальной академии государственного управления при Президенте Украины; 0558855@mail.ru
} 
образовательных программ, основанных на принципах дифференциации и персонализации.

Ключевые слова: территориальная община, местное публичное управление, местное самоуправление, участие жителей, привлечение населения, реализация права на местное самоуправление.

\section{1. ВВЕДЕНИЕ}

Местное самоуправление не является тождественным общественному самоуправлению и, как легитимная форма самоорганизации местныхсообществ, характеризуется политическим, гражданским и правовым аспектами, имеет институционную структуру, то есть является системой деятельности местных общин в сфере управления общественными и некоторыми государственными делами, адаптируя их к местным потребностям и условиям жизни населения. Местное самоуправление, как первичный уровень публичной власти и системы управления в государстве, в современном мире признается единственно возможным демократическим институтом управления местным сообществом, которое опирается на правовые нормы, а также традиции, обычаи и общественное мнение членов общины. Такая форма осуществления местной власти непосредственно приближена к жителям, что даёт возможность обеспечивать их потребности и интересы, участвовать в решении вопросов местной жизни.

В условиях реформирования публичного управления в Украине особенного внимания заслуживает необходимость использования потенциала самоорганизации населения в процессе решения местных проблем. Недостаточный уровень участия населения в принятии управленческих решений на локальном уровне, обусловленный причинами объективного и субъективного характера, актуализирует проведение исследований, посвящённых теоретическому обоснованию новых направлений привлечения членов территориальной общины к местной публичной жизни, а также разработку мер, направленных на повышение роли территориальной общины в осуществлении местного самоуправления.

В связи с этим, целью статьи является анализ сущности территориальныхобщин в Украине, выделение их специфических признаков в зависимости от определённого уровня, а также рассмотрение проблемных вопросов участия населения в местном самоуправлении и внесения предложений относительно повышения уровня участия населения в решении вопросов местного значения.

\section{2. ОБОБЩЕНИЕ ПОДХОДОВ ОТНОСИТЕЛЬНО РЕАЛИЗАЦИИ ЧЛЕНАМИ ТЕРРИТОРИАЛЬНОЙ ОБЩИНЫ ПРАВА НА МЕСТНОЕ САМОУПРАВЛЕНИЕ}

Местное самоуправление, как первичный уровень публичной власти и системы управления в государстве, в современном мире признается единственно возможным демократическим институтом управления местным сообществом, которое опирается на правовые нормы, а также традиции, обычаи и общественное мнение членов общины. Такая форма осуществления местной власти непосредственно приближена к жителям, что даёт возможность удовлетворять их потребности и интересы, участвовать в решении вопросов местной жизни. Местное самоуправление не является тождественным общественному самоуправлению и, как легитимная форма самоорганизации местных сообществ, характеризуется 
политическим, гражданским и правовым аспектами, имеет институционную структуру, то есть является системой деятельности местных общин в сфере управления общественными и некоторыми государственными делами, адаптируя их к местным потребностям и условиям жизни населения.

Местное самоуправление, как институт публичной власти, имеет общественный характер и распространяется на всех членов общины, в частности на жителей каждой административно-территориальной единицы. Как замечает М. Баймуратов, при всем единстве публичной власти имеет место и существенная разница в её субъектном составе. Для публично-самоуправленческой власти характерно, что она осуществляется не государством, а специальным субъектом, который имеет особенный объект управления и другие имманентные качества, присущие такой власти ${ }^{3}$. Им выступают непосредственно жители городов, поселков и сел, объединённые в местные общины или представительские органы в лице советов, которые избираются жителями и действуют в интересах населения соответствующей общины. Низовые территориальные сообщества составляют наиболее общую субъектную основу местного самоуправления. Внешней формой их формального выражения в Украине выступают территориальные общины.

Обобщение разных подходов относительно сущности местных общин позволяет выделить виды территориальныхобщин в зависимости от их предметной деятельности, направленной на удовлетворение определённых потребностей (получение качественных услуг) в пределах конкретной территории проживания жителей общины. Как видится, первый уровень представлен территориальными общинами сел, поселков или городов, которые осуществляют свои полномочия непосредственно или через органы местного самоуправления. На втором уровне находятся объединения территориальных общин сел, поселков и городов. Такие объединения могут иметь характер постоянных или временных, что зависит от осуществляемых совместных проектов, при этом права и обязанности относительно реализации заданий по проектам будут осуществлять соответствующие местные советы. Третий уровень составляют «микрообщины», которые включают общины района в городе, микрорайон, квартал, улицы, дома и могут реализовать право на местное самоуправление непосредственно, через органы местного самоуправления или органы самоорганизации населения.

Несмотря на то, что основное бремя функциональной нагрузки относительно решения вопросов местного значения возложено на органы местного самоуправления, согласно украинскому законодательству территориальная община, как субъект местного самоуправления, имеет такие специфические признаки:

- признание и гарантированность деятельности территориальной общины как субъекта местного самоуправления на конституционном уровне;

- право жителей территориальной общины на местное самоуправление является специфической формой народовластия;

- местное самоуправление территориальной общины осуществляется с соблюдением прав и свобод человека и гражданина;

- законодательство закрепило возможность реализации права на местное самоуправление с помощью представительской или непосредственной демократии,

\footnotetext{
${ }^{3}$ Баймуратов М. А. Муниципальная власть: актуальные проблемы становления и развития в Украине : монография / М. А. Баймуратов, В. А. Григорьев. - О. : Юридическая литература, 2003. - С.14.
} 
которая предусматривает такую форму осуществления управленческихполномочий как самоорганизация и формирование соответствующих управленческих органов;

- самостоятельность территориальной общины при решении вопросов местного значения;

- единство прав и обязанностей территориальной общины;

- деятельность территориальной общины проходит в пределах и порядке, определённом действующим законодательством;

- территориальная община выступает одновременно в качестве объекта и субъекта управленческой деятельности;

- компетенция территориальной общины ограничивается решением вопросов местного значения;

- публичная власть территориальной общины носит локальнопространственный характер;

- обеспеченность и гарантирование праваграждан на местное самоуправление предусмотрена на конституционном и законодательном уровнях.

\section{3. ПРОБЛЕМЫ УЧАСТИЯ ЧЛЕНОВ ТЕРРИТОРИАЛЬНОЙ ОБЩИНЫ В МЕСТНОМ САМОУПРАВЛЕНИИ УКРАИНЫ}

При разработке механизмов реализации гражданами права на местное самоуправление, которое предусматривает также привлечение жителей территориальных общин к решению вопросов местного значения органами местного самоуправления, необходимо учитывать вид населённого пункта - села, посёлка или города. От этого зависит непосредственное и опосредованное взаимодействие жителей определённой территории, межличностное общение, общий труд и отдых, общее пользование ресурсами территории, а также общие системы управления и распределения. В малых поселениях важную роль играют непосредственные контакты, общий труд, тесные семейные связи. В больших населённых пунктах преобладают связи опосредствованные общими инфраструктурными, производственными, управленческими элементами. Это является «объективной причиной формирования разных факторов самоуправленческой активности территориальных сообществ и разной организации механизмов самоуправления на территориях разного уровня» ${ }^{4}$.

Подавляющее большинство жителей городов получают информацию о деятельности местной власти через средства массовой информации. Определённая прослойка населения получает информацию через информационные городские сайты и сайты городских советов. К сожалению, они не содержат проекты документов, которые будут рассматриваться, а также решения, которые принимаются городскими советами. Общественные слушания проводятся в городах, как правило, не с целью услышать мнение жителей относительно очередного повышения коммунальных платежей, а предоставить информацию о неизбежности такого повышения, убедить население в необходимости осуществления такого шага. Кроме этого, если общественные слушания проводятся в течение рабочего дня, то большинство наёмных работников города не могут участвовать у них, территориальную общину

\footnotetext{
4 Демьянов Е. А. Территориальная общность как субъект самоуправленческой активности / Е. А. Демьянов // Проблемы местного самоуправления. - 2004. - № 2 (10). - С. 20 - 24.
} 
при этом представляют неработоспособные лица и представители общественных организаций.

Формы и методы взаимодействия жителей сел и поселков с представителями органов местного самоуправления являются несколько иными, принимая во внимание относительно небольшое количество членов местной общины, наличие очень стойких социальных связей между его членами, в том числе и с должностными лицами соответствующих советов и исполкомов. Поэтому общение с сельскими и поселковыми должностными лицами может проводиться лично во время визита в исполком поселкового или сельского совета, или на собрании жителей. Как считает Н. Мишина, сельский сходы являются наиболее приемлемой формой локальной демократии для сельских населённых пунктов ${ }^{5}$. Это подтверждается и распространённой практикой их проведения. Впрочем полученная таким образом информация, как правило, касается уже принятых решений относительно жизни определённой территории. На принятие большинства проектов решений граждане практически не имеют возможности влиять. Хотя именно такое общение, в первую очередь, направлено на возможность для жителей отдалённых сел решить свои проблемы местного значения.

\section{4. ПРАКТИЧЕСКИЙ ОПЫТ ПРИВЛЕЧЕНИЯ ЧЛЕНОВ ТЕРРИТОР ИАЛЬНЫХ ОБЩИН В УКРАИНЕ К РЕШЕНИЮ ВОПРОСОВ МЕСТНОГО ЗНАЧЕНИЯ}

В повышении эффективности осуществления местного самоуправления на территории общины важное место занимает изучение мнения и выявление приоритетов для населения в местной жизни. Наиболее целесообразным инструментом изучения общественного мнения остаются опрос и анкетирование. Как свидетельствует практика, опросы, которые проводятся органами местного самоуправления, являются действенной мерой определения приоритетов их работы в интересах местного населения. Подтверждением этому является опыт города Комсомольска, где было отобрано двадцать неотложных проблем города и задан вопрос жителям относительно определения уровня их важности. Результаты удивили местную власть тем, что те проблемы, на которые было потрачено больше всего средств и времени, не были первоочередными для общины, а на первом месте оказались вопросы, которым власть не уделяла внимания. Согласно этому опросу, главные для населения проблемы начали обсуждаться на общественных слушаниях и были реализованы соответствующие программы ${ }^{6}$.

Результаты опросов украинских граждан относительно степени доверия власти свидетельствуют о том, что население больше доверяет местным советам по сравнению с региональным и государственным уровнем ${ }^{7}$. По мнению Г. Линевича,

\footnotetext{
${ }^{5}$ Мішина Н. Органи самоорганізації населення в населених пунктах міської та міської місцевості. Режим доступу : http:/www.library.oridu.odessa.ua/. - Назва з екрану.

${ }^{6}$ Самостійність місцевих влад та розподіл повноважень між ними: організація місцевого самоврядування відповідно до принципів Свропейської хартії місцевого самоврядування : матеріали міжн. конф., м. Київ, 11-12 черв. 2002 р. / упоряд. В. Кравченко, М. Пухтинський. - К. : Логос, 2002. - С. 90-91.

7 Линевич Г. Підстави для довіри і підтримки. Їх в Україні має лише місцева влада, в чому переконують черкаські самоврядні ініціативи // Розвиток громад і регіонів України / В. Гудак, Г. Линевич, О. Бойко Бойчук [та ін.] ; за ред. С. Максименка. - К.: Логос, 1999. - С. 14 - 15.
} 
конкретным проявлением развития общины является объединение граждан на уровне микрорайонов, городских кварталов или улиц с целью решения общих проблем (начиная от оборудования детских площадок до проблем коммунальной сферы). Он предлагает как образец модель «процесса социального действия», которое включает такие этапы: выявление инициаторов (группа жителей); обсуждение возможных вариантов достижения цели; разработка конкретного плана; аккумулирование всех необходимых факторов и ресурсов через информирование по радио, телевидению, газеты и тому подобное; проведение и окончание работ. Такая модель является достаточно эффективной, принимая во внимание создание управления микрорайона, которое включает наиболее активных и инициативных жителей. Постоянным рабочим органом является правление, в состав которого, кроме жителей, входят депутаты городского и районного советов, избранные от микрорайона. Еженедельно правление на рабочих совещаниях разрешает текущие проблемы и при необходимости они выносятся на рассмотрение исполкома совета ${ }^{8}$.

В городе Первомайске ещё в 1999 году была введена новая технология привлечения населения и представителей деловых кругов города к решению социально значимых для городской общины проблем путём организации конкурсов и выдачи грантов из бюджета развития, а также введён ещё ряд инициатив налаживании диалога с жителями. Такие местные инициативы были восприняты городским советом достаточно осторожно, поскольку они задевали многочисленные личные и групповые интересы и выявили ряд проблем и противоречий ${ }^{9}$. Сегодня такие инструменты привлечения жителей к местному публичному управлению используются органами местного самоуправления достаточно часто.

Среди городов Украины, которые первыми начали и продолжают активно привлекать общественность к процессу принятия решений, следует выделить Комсомольск, Бердянск, Славутич и другие ${ }^{10}$. Например, в Комсомольске были проведены первые в Украине общественные слушания «Политика Комсомольского городского совета на современном этапе в решении городских проблем, которые сложились в сфере жизнедеятельности города в период экономического кризиса». Кроме этого, местная власть Комсомольска использует разнообразные формы и методы взаимодействия с местным населением. К ним относятся: общественные слушания, опросы общественного мнения, создания групп волонтёров, мероприятия относительно общественного просвещения населения путём сотрудничества с местными СМИ, привлечения жителей общества к социально-экономическому развитию города и стратегическому планированию ${ }^{11}$.

Большое значение для развития общинного самоуправления имеет реализация Программы развития ООН (дальше - ПРООН). Эта программа способствует

\footnotetext{
${ }^{8}$ Там же, с.18-19.

${ }^{9}$ Бойко-Бойчук О. Влада, бізнес і громада: шлях до конструктивного діалогу / О. Бойко-Бойчук // Розвиток громад і регіонів України: [Проект Київського центру Ін-ту Схід-Захід] / В. Гудак, Г. Линевич, О. Бойко-Бойчук [та ін.] ; за ред. С. Максименка. - К. : Логос, 1999. - С. 62-63.

${ }^{10}$ Драган I. В. Сучасний стан взаємодії органів державного управління та місцевого самоврядування України з громадськістю / І. В. Драган // Держава та регіони. (Сер. «Державне управління») - 2007. № 3. - C. 67.

${ }^{11}$ Шара Л. Кращий досвід громадських слухань в Україні / Л. Шара. - К. : Фонд «Європа XXI», 2002. C.24,27.
} 
установлению партнёрских отношений и распространяет положительный опыт в сфере расширения участия граждан в управлении, повышения ответственности власти и улучшения работы на всех уровнях. Кроме этого, ПРООН стремится помочь и поддержать субъекты местного самоуправления в вопросах повышения уровня предоставления разным слоям населения высококачественных общественных услуг. С момента подписания базового соглашения о предоставлении помощи ПРООН Украине в 1993 г. общие проекты ПРООН и Украины направлены на продвижение главных принципов демократического самоуправления на всех уровнях путём поддержки административной реформы и привлечения граждан к участию в процессе принятия решений. Введение ПРООН проектов в сфере местного самоуправления и их финансовая поддержка со стороны ЕС, сделали возможным значительное распространение положительного опыта относительно реализации проектов, ориентированных на социальное развитие общин Украины. На основе применения территориального подхода развивается потенциал партнёров проекта с целью привлечения жителей местных общин к самопомощи и решению местных проблем ${ }^{12}$.

Учитывая приобретённый положительный совместный опыт Украины и европейских организаций по вопросам местного развития можно сделать вывод, что благосостояние территориальной общины и её успешное развитие в значительной степени зависит от формирования партнёрских отношений и координации совместной деятельности при решении местных проблем в системе власть общество. Такое сотрудничество является следствием реализации одного из важнейших принципов демократического самоуправления - участия населения в процессах управления на всех его уровнях.

Сегодня в исследование взаимодействия территориальной общины и местных органов власти вводится новый термин - «социальное партнёрство», который ещё до недавнего времени применялся только как средство достижения социального баланса между наёмными работниками, работодателями и государством, а в последнее время между органами государственной власти и общественными организациями ${ }^{13}$, а также через тесное социальное сотрудничество бизнеса, власти и жителей территориальной общины ${ }^{14}$. Как видится, с целью повышения уровня обеспечения жителей территориальных общин сел, поселков и городов надлежащими услугами необходимо рассматривать установление отношений социального партнёрства как один из элементов взаимодействия на местном уровне между тремя субъектами: территориальным обществом, муниципальными органами, органами государственной власти. Сюда также можно включить, как отдельные стороны бизнес-структуры, предприятия разных форм собственности. Преимуществом социального партнёрства является равноправное участие всех субъектов местного самоуправления в осуществлении местного публичного управления.

\footnotetext{
${ }^{12}$ Напрями національної політики участі громадян у місцевому сталому розвитку : аналіт. документ № 1 , січень 2007 р. - К. : Компанія BAITE, 2006. - С.11.

${ }^{13}$ Новак В. В. Організаційно-правові питання соціального партнерства органів державної влади та громадських об'єднань в Україні : стан та перспективи розвитку : автореф. дис... канд. наук з держ. упр. : 25.00.01 / Новак Валентин Володимирович ; Інститут законодавства Верховної Ради України. К., 2008. - C.

${ }^{14}$ Бобровська О. Ю. Розвиток форм соціального партнерства в муніципальних утвореннях / О. Ю. Бобровська // Держава та регіони : наук.-вироб. журнал/ редкол. : В.Л. Корінєв (голов. ред.) [та ін.]. Запоріжжя : Гуманітарний університет «ЗІДМУ», 2007. - № 3. - С. 17 - 22.
} 
Под социальным партнёрством Е. Демьянов понимает совместную деятельность социальных объектов по достижению интересов, которые взаимно перекрещиваются (частично или полностью совпадают). Основанием социального партнёрства при этом является развитие структур местного самоуправления, повышение их деятельности через привлечение самоуправленческой активности территориальной общины ${ }^{15}$.

Развитие социального партнёрства на уровне местное самоуправление государственная власть обусловлено тем, что, как формы публичной власти, они имеют единое происхождение и объективно не могут быть антагонистами и противодействовать друг другу. Невзирая на их функционирование на разных уровнях, они имеют единую правовую природу, в результате чего «обречены» на сосуществование и тесное взаимодействие ${ }^{16}$. По мнению С. Крыжановского, отношения между субъектами местного самоуправления и государственными органами могут быть урегулированы путём отказа от практики делегирования большого количества полномочий и передачи территориальным общинам прав и полномочий, которыми владеет государство. Социальное партнёрство же представительских органов территориальной общины с жителями должно быть, в первую очередь, направлено на деятельность органов местного самоуправления в сторону обеспечения интересов и потребностей обычного человека, который проживает на территории общины ${ }^{17}$. Такие отношения могут закрепляться на местном уровне специальным Соглашением о социальном (межсекторном) партнёрстве. Детализация отношений в зависимости от разных вопросов местной жизни может осуществляться специальными дополнительными договорами о взаимодействии, как это делается в Великобритании.

Позитивным для использования также является опыт Нидерландов, где в начале 1980-х гг. был принят закон о благосостоянии населения, направленный на обеспечение потребностей жителей общин. Главным принципом политики является социальное партнёрство и поиск достижения консенсуса в обществе. Например, из бюджета города Гааги значительная сумма выделяется на выполнение задачи по взаимодействию с населением. Каждый муниципалитет имеет свои научные отделы, которые занимаются выявлением потребностей жителей, их мнения, проблем. В небольшом городке Арнем проводятся около 20 опросов ежегодно, ведётся статистика, постоянный мониторинг общественного мнения, которое является основанием для выработки социальной политики в городе, отвечающей запросам жителей. Если должно проводиться строительство, то обязательно проводятся консультации с населением, общественными организациями. Для предоставления социальных услуг населению проводятся конкурсы или тендеры. Муниципалитет может передать выполнение некоторых своих функций органу территориального общественного самоуправления ${ }^{18}$.

15 Демьянов Е. А. Территориальная общность как субъект самоуправленческой активности / Е. А. Демьянов // Проблемы местного самоуправления. - 2004. - № 2 (10). - С. 23.

${ }^{16}$ Глухачов Ф. Місцеве самоврядування в Україні: особливості його правової природи / Ф. Глухачов // Актуальні проблеми державного управління. - 2001. - № 1. - С. 41.

${ }^{17}$ Крижанівський С. Територіальній громаді - належні повноваження / С. Крижанівський // Місцеве самоврядування. - 1998. - № 5 - 7 (14). - С. 139 - 140.

${ }^{18}$ Гаврилова И. Н. Местноесамоуправление и социальное партнерство в Нидерландах / И. Н. Гаврилова // Государственная власть и местное самоуправление. - 2005. - № 4. - С. 25. 
К сотрудничеству органов местного самоуправления и территориальных общин могут быть привлечены общественные советы. В демократических странах местная власть, как правило, сотрудничает с общественными совещательными комитетами. Их функции заключаются в содействии привлечению граждан к участию в процессах управления, а также информировании власти о потребностях граждан. В Украине недостаточная эффективность их деятельности связана с тем, что члены общины не заинтересованы в создании и функционировании таких органов. Их созданию мешает высокий уровень недоверия между властью и жителями, отсутствие определения их основных заданий, целей и функций деятельности, политическая ангажированность, игнорирование местной властью решений и рекомендаций общественных советов, отсутствие организационного, финансового обеспечения деятельности. Эти проблемы не могут быть устранены быстро, но, по инициативе органов местного самоуправления, которые готовы услышать мнение жителей и привлечь их к участию в управленческой деятельности, такая форма сотрудничества станет возможной в большинстве городов Украины. Конечно, более логичным является создание общественных комитетов по решению группы инициативных граждан. При этом местная власть должна поддерживать такие начинания и оказать соответствующую материально-техническую и организационную поддержку, которая касается выделения места для проведения заседаний, подготовки повестки собраний, обеспечения доступа к информации совета и др.

Образование общественных советов имеет смысл в том случае, когда есть проблемы, решение которых требует постоянного участия населения. Поэтому целесообразно органу местного самоуправления сначала определить такие вопросы, а потом включиться в процесс деятельности общественного совета. Все это необходимо отображать в специальных положениях, утверждённых местным советом, учитывая тип общественного образования (постоянный или временный). Постоянные общественные советы могут заниматься вопросами бюджета и планирования, экономического развития, общественного транспорта, санитарии, жилья, образования, вопросами нетрудоспособных лиц и др. Временные советы могут образовываться для реализации конкретных проектов местных органов власти. Определение направления деятельности имеет большое значение для практической работы общественного совета, потому что именно это является признаком серьёзности и необходимости его образования. Полезные рекомендации общественных советов и положительные результаты их действий со временем приведут к одобрительной оценке жителями, а также повышению заинтересованности в их деятельности.

С целью организации изучения потребностей территориальной общины возможно в местных советах создавать отделы по соответствующим вопросам, которые бы занимались собственными исследованиями, обращаясь к независимым экспертам, местным организациям по вопросам мониторинга, общественным организациям относительно разработки и реализации методологии проведения исследований. Эффективность работы созданного специализированного отдела местного совета зависит от подбора и привлечения высококвалифицированных кадров, а деятельность внешней организации будет иметь пользу только в случае привлечения независимого профессионального исполнителя с достаточной институционной возможностью и позитивным имиджем, политически непредвзятого. 


\section{5. УПРАВЛЕНЧЕСКОЕ ОБРАЗОВАНИЕ НАСЕЛЕНИЯ КАК НАПРАВЛЕНИЕ ПОВЫШЕНИЯ УРОВНЯ УЧАСТИЯ ЧЛЕНОВ ТЕРРИТОРИАЛЬНОЙ ОБЩИНЫ В МЕСТНОМ САМОУПРАВЛЕНИИ}

Значительное количество граждан Украины не реализует предоставленное им право на участие в решении вопросов местного значения из-за незнания механизмов его реализации, а потому не может быть партнёром местной власти во время принятия управленческих решений и участия в управлении местными делами. Опыт развитых демократических стран свидетельствует о том, что переход к новой системе местного самоуправления, изменения в отношениях граждан и публичной власти не обходятся без управленческого образования населения. В странах Западной Европы и Северной Америки существуют общественные движения за доступ граждан кучастию в местном самоуправлении, которые занимаются вопросами муниципального просвещения. Несомненно, Украине нужна общегосударственная программа образования по вопросам местного самоуправления, в основе которой была бы идея свободного доступа граждан к участию в местном публичном управлении. Кроме этого, на местном уровне также необходимо разрабатывать образовательные программы, основанные на принципах дифференциации и персонализации, то есть с учётом особенностей социального статуса, возраста, пола, культурного уровня людей.

Разработкой мероприятий относительно муниципального образования граждан должны заниматься специалисты по вопросам местного самоуправления, которые имеют соответствующее управленческое образование. Приобретённая в результате учёбы управленческая компетенция будет сочетать в себе как теоретическую подготовку, так и практический опыт управленческой деятельности в органах местного самоуправления. Особенно это важно при нынешнем низком уровне управленческой культуры как населения, так и должностных лиц местного самоуправления, которые не всегда понимают сущность государственноуправленческих процессов, не чувствуют связи между выполнением должностных инструкций и своим участием в муниципальном управлении, осознавая себя только наёмными работниками органа местного самоуправления. Получения тех знаний, которые предусмотрены программой профессиональной подготовки и переподготовки в рамках повышения квалификации, является недостаточным для применения их на практике. Заниматься самостоятельно учёбой избранные и должностные лица местного самоуправления не имеют возможности из-за значительной служебной нагрузки. Поэтому важной является разработка системы обучения депутатов местных советов и должностных лиц местного самоуправления по вопросам взаимодействия с местной общиной, что будет содействовать повышению как их муниципальной культуры, так и возможности привлечения граждан к решению вопросов местного значения.

\section{6. ВЫВОДЫ}

В значительной степени повышение уровня участия членов территориальной общины в местном публичном управлении зависит как от активности самих жителей, так и от желания управленцев допускать и привлекать население к решению вопросов локального значения. Обобщение опыта деятельности органов местного самоуправления в Украине показывает, что инициатива местных органом власти 
всегда находит отклик со стороны граждан. В условиях демократизации местного публичного управления в Украине основной задачей органов местного самоуправления является использование тех механизмов, которые позволят убедить население в важности активного участия в управленческих процессах.

\section{ЛИТЕРАТУРА}

[1] Баймуратов М. А. Муниципальная власть: актуальные проблемы становления и развития в Украине : монография / М. А. Баймуратов, В. А. Григорьев. - О. : Юридическая литература, 2003. - 248 с.

[2] Беззубко Л. В. Про деякі механізми взаємодії членів громади з органами місцевого самоврядування / Л. В. Беззубко, О. В. Скопець // Менеджер. - 2007. - № 1 (39). - С. $76-81$.

[3] Бобровська О. Ю. Розвиток форм соціального партнерства в муніципальних утвореннях / О. Ю. Бобровська // Держава та регіони : наук.-вироб. журнал / редкол. : В.Л. Корінєв (голов. ред.) [та ін.]. - Запоріжжя : Гуманітарний університет «ЗІДМУ», 2007. - № 3. С. $17-22$.

[4] Бойко-Бойчук О. Влада, бізнес і громада: шлях до конструктивного діалогу / О. БойкоБойчук // Розвиток громад і регіонів України: [Проект Київського центру Ін-ту СхідЗахід] / В. Гудак, Г. Линевич, О. Бойко-Бойчук [та ін.] ; за ред. С. Максименка. - К. : Логос, 1999. - С. $62-68$.

[5] Гаврилова И. Н. Местное самоуправление и социальное партнерство в Нидерландах / И. Н. Гаврилова // Государственная власть и местное самоуправление. - 2005. - № 4. - С. $24-26$.

[6] Глухачов Ф. Місцеве самоврядування в Україні: особливості його правової природи / Ф. Глухачов // Актуальні проблеми державного управління. - 2001. - № 1. - С. 39 - 44.

[7] Демьянов Е. А. Территориальная общность как субъект самоуправленческой активности / Е. А. Демьянов // Проблемы местного самоуправления. - 2004. - № 2 (10). - С. $20-24$.

[8] Драган I. В. Сучасний стан взаємодії органів державного управління та місцевого самоврядування України з громадськістю / І. В. Драган // Держава та регіони. - 2007. № 3. - С. 67 - 72. - (Сер. «Державне управління»).

[9] Крижанівський С. Територіальній громаді - належні повноваження / С. Крижанівський // Місцеве самоврядування. - 1998. - № 5 - 7 (14). - С. 137 - 140.

[10] Линевич Г. Підстави для довіри і підтримки. Їх в Україні має лише місцева влада, в чому переконують черкаські самоврядні ініціативи // Розвиток громад і регіонів України / В. Гудак, Г. Линевич, О. Бойко-Бойчук [та ін.] ; за ред. С. Максименка. - К. : Логос, 1999. - С. $14-19$.

[11] Напрями національної політики участі громадян у місцевому сталому розвитку : аналіт. документ № 1, січень 2007 р. - К. : Компанія ВАITE, 2006. - 36 с.

[12] Новак В. В. Організаційно-правові питання соціального партнерства органів державної влади та громадських об'єднань в Україні : стан та перспективи розвитку : автореф. дис... канд. наук з держ. упр. : 25.00.01 / Новак Валентин Володимирович ; Інститут законодавства Верховної Ради України. - К., 2008. - 20 с.

[13] Самостійність місцевих влад та розподіл повноважень між ними: організація місцевого самоврядування відповідно до принципів Європейської хартії місцевого самоврядування : матеріали міжн. конф., м. Київ, 11-12 черв. 2002 р. / упоряд. В. Кравченко, М. Пухтинський. - К. : Логос, 2002. - 263 с.

[14] Мішина Н. Органи самоорганізації населення в населених пунктах міської та міської місцевості. - Режим доступу : http:/www.library.oridu.odessa.ua/. - Назва з екрану.

[15] Шара Л. Кращий досвід громадських слухань в Україні / Л. Шара. - К. : Фонд «Европа

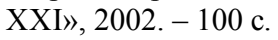




\section{TERRITORIAL COMMUNITY PARTICIPATION IN LOCAL PUBLIC ADMIN- ISTRATION: PROBLEMS AND WAYS OF THEIR DECISION}

The article considers the problems of the low level participation of villages, settlements, towns, cities territorial communities in decision making issues of local character in Ukraine and the ways of solutions which are offered. The processes of different mechanisms of citizens' involvement to participate in local public administration in the towns in Ukraine are described. They are based on examination of opinions and identification of priorities for population as to local life by conducting public inquiries and polls, announcement of competitions and grants, participation in the Development Program of the UNO.

The article examines the concept of "social partnership" among the territorial community, municipal bodies and state authorities, representatives of business structures, enterprises of different forms ownership. The importance of such directions of interaction of actors in the field of local self-government, which is carried out on a parity basis to involve local people in the process of implementation of the local public administration in the conditions of reforming local self-government in Ukraine, is defined. The issues that should be dealt with permanent and temporary public councils that may be relevant to the practical work of the public council and affect the efficiency of its activities are distinguished. The necessity to carry out institutional changes in local self-government bodies and raise the level of urban education of deputies of local councils, local government officials and citizens within the framework of the national program of education for local self-government is proved. It is offered to use local educational programs based on the principles of differentiation and personalization for citizens.

Keywords: territorial community, local public administration, local self-government, the participation of inhabitants.

\section{DOI: 10.7862/rz.2014.mmr.37}

Tekst złożono w redakcji: wrzesień 2014

Przyjęto do druku: październik 2014 